\title{
The rise and fall of Hungarian complex tenses
}

Katalin É. Kiss (Linguistics Institute of the Hungarian Academy)

\author{
ekiss@nytud.hu
}

\section{Goals}

This paper aims to reconstruct how and why complex tenses appeared in Hungarian grammar in the late Proto-Hungarian period, and how and why they disappeared 1000 years later. It will show that the evolution of complex tenses started with a micro-change: the reanalysis of the feature content of a verbal suffix. This step initiated further processes of reanalysis, analogical extension, and abstraction, as a consequence of which the tense system inherited from Uralic, distinguishing only past and non-past, developed into a complex system marking both tense and viewpoint aspect. The paper will argue that both the appearance of complex tenses, and their disappearance, i.e., the replacement of morphological viewpoint aspect marking by situation aspect marking via verbal particles, was triggered by language contacts and will speculate about the conditions that make a grammatical construction susceptible to foreign influence.

The paper is structured as follows: Section 2 introduces the complex tenses of Old Hungarian, marking both tense and viewpoint aspect. Section 3 argues against the traditional view that they are the artificial creations of scribes translating from Latin. Section 4 shows that they must have appeared in Proto-Hungarian under the influence of Old Turkic. Section 5 attempts to reconstruct which Old Turkic construction served as a model for Proto-Hungarian, what changes it triggered in Proto-Hungarian, and how the changes unfolded. Section 6 describes a change that took place in Hungarian a thousand years later, in the course of which the extension of telicity marking by resultative verbal particles, presumably induced by Slavic influence, developed into an alternative aspectual system, marking situation aspect. Section 7 shows how situation aspect marking made viewpoint aspect marking redundant, and led to the disappearance of complex tenses. Section 8 summarizes the theoretical implications of the changes observed.

\section{Complex tenses in Old Hungarian}

Whereas Modern Hungarian only has two tenses: past and non-past, Old Hungarian had a complex tense system marking both tense and viewpoint aspect. In Old Hungarian texts, we attest the following tenses: 
(1) i. Simple Present, e.g.:

mond-Ø-om

say-PRES-1SG

ii. Simple Past:

mond-á-m

say-PAST-1SG

iii. Present Perfect:

mond-t-am

say-PERF-1SG

iv. Past Imperfective/Continuous:

$\begin{array}{ll}\text { mond-Ø-om } & \text { val-a } \\ \text { say-IMPERF-1SG } & \text { be-PAST }\end{array}$

v. Past Perfect:

mond-t-am val-a

say-PERF-1SG be-PAST

In the simple tenses, the lexical verb bears tense and agreement morphemes. In the complex tenses, the lexical verb is marked for aspect and agreement, and the tense morpheme is borne by the copula serving as a temporal auxiliary. Old Hungarian also had simple conditional and conditional perfect verb forms. In the simple conditional, the verb bears mood and agreement morphemes. In the conditional perfect, the verb is marked for aspect and agreement, and the auxiliary is marked for mood:
vi. Simple Conditional:
monda-ná-m
say-COND-1SG
vii. Conditional Perfect:
mond-t-am vol-na
say-PERF-1SG be-COND

In Old Hungarian, the different tense-aspect combinations had similar values as they have e.g. in present-day English. Thus the simple present was used to describe events that include or follow the speech time. The simple past, also called narrative past, was the default past tense used e.g. in story telling. The present perfect marked past events with a result still in effect at the speech time. The difference between the functions of the simple past and the present perfect is illustrated by a Biblical citation from the Book of Ruth, where the story teller relates the event of Orpah turning back by using simple past, whereas Naomi, witnessing Orpah walking away, refers to the event by present perfect.
(2) Orpha megapol-a
o napat
$\&$
mėǵfordol-a. Rvt èggèsọlè ọ 
Orpah kiss-PAST.3SG her mother.in.law.ACC and turn-PAST.3SG Ruth united her napaual Kinç mōd-a Noemi Ime te rokonod mèǵfordol-t mother.in.law.with whom tell-PAST.3SG Noemi behold your relative turn-PERF.3SG

'Orpah kissed her mother in law and turned back. Ruth clave onto her mother in law. Naomi told her: Behold, your relative has turned back.' (Vienna Codex 1416, p. 2)

The past continuous verb forms marked past events in progress - see (3a), habitual past events - see (3b), and incomplete past achievements - see (3c), a sentence from the story of Adam and Eve.

(3)a. mend czudal-yak ual-a Es halgat-yak uala ewtett all admire.3PL be-PAST and listen-3PL be-PAST him 'They were all admiring him and listening to him' (Jókai Codex 1370, p. 37)

b. Ez nemesseges zent zvz $\ldots$ hetet tart-Ø val-a az cohnyan this noble saint maid week.ACC keep-IMPERF.3SG be-PAST the kitchen.at fevz-Ø val-a az sororoknak cook-IMPERF.3SG be-PAST the sisters.DAT 'This noble saint maid would have turns on duty at the kitchen, she would cook for the sisters'

(Legend of Saint Margaret, 1510, p. 12 verso)

c. Es oz gimilsnec wl keseruv uola vize. hug turchucat mige and that fruit.DAT so bitter was water.3SG that throat.3PL.ACC PRT zocozt-ia vol-a. burst-IMPERF.3SG be-PAST

'And that fruit had such a bitter juice that it was bursting their throats.'

(Funeral Speech and Prayer 1195)

The past perfect marked past events preceding a past reference point, e.g.:
(4) És megemlékez-é-k
Péter az igéről,
kit mondo-tt val-a and commemorate-PAST-3SG
Peter the word.about
that say-PERF.3SG be-PAST 
'And Peter commemorated the word that he had told them.' (München Codex 1416, p. 103)

As illustrated by these data, the Old Hungarian tense system encoded not only the external tense of events, but also the viewpoint of the speaker. It marked whether the speaker's perspective included the whole event, or only an internal section of it, i.e., it marked, in addition to tense, also viewpoint aspect.

\section{The traditional view about the origin of complex tenses: Latin influence}

Since the majority of the Uralic languages, including Mansi and Khanty, the closest relatives of Hungarian, only have two tenses: past and non-past, traditional historical linguists assume that the complex tenses of Old Hungarian were artificially created by scribes translating from Latin in order to distinguish the different Latin past tenses (E. Abaffy 1991, 109-110; Sárosi 2005, 367).

This view, however, is untenable for both theoretical and empirical reasons. If grammar changes when children acquiring a construction analyze it differently from the way their parents analyze it, then a scholarly second language learned at an older age is unlikely to lead to major changes in the native grammar. Empirical considerations also argue against deriving the complex tenses from Latin influence. First of all, Latin has no complex tenses in the active voice. The Romance languages have complex tenses, but they are structured differently from those of Old-Hungarian (the agreement suffix is on the auxiliary, instead of the lexical verb). Secondly, the complex tenses were present in Old Hungarian before large scale translation from Latin (e.g., the translation of the Bible) began. The very first surviving Hungarian text, the Funeral Sermon and Prayer from 1195, which is believed not to be a translation, contains both past perfect and past continuous verb forms:

(5)a. es odut-t-a vol-a neki paradisumut hazoa and give-PERF-3SG be-PAST him Paradise.ACC house.for 'and had given him Paradise for his house'

b. turchucat mige zocozt-ia vol-a throat.3pl.ACC up split-IMPERF.3SG be-PAST 'it was splitting up their throat' 
Thirdly, the complex tenses are also found in Old Hungarian private letters, as testified, e.g., by the letters edited by Hegedüs \& Papp (1991). Fourthly, if Old Hungarian had no standardized language, and the same set of complex tenses is attested in codices written in different parts of the country, then it is unlikely that we are dealing with the scribes' inventions. Fifthly, although the complex tenses disappeared from most varieties of Hungarian in the 16th-17th centuries, they are still attested in the most archaic EastHungarian dialects, including the Csángó dialect spoken in Moldavia, which has never had any written form and any literate speakers - see, e.g., the Csángó corpus collected by Szegő (1998). Standard Hungarian has also preserved a complex verb form, the conditional perfect (analyzed as past conditional in the synchronic system):

(6) mond-tá-tok vol-na

SAy-PERF-2PL be-COND

'you would have said'

In view of these facts, the possibility that the Old Hungarian complex tenses evolved as a consequence of Latin influence, can be excluded.

\section{An alternative explanation: Old Turkic contact effect}

Bereczki (1983; 1993) proposed an alternative explanation for the emergence of complex tenses in Hungarian. He observed that there are five Uralic languages that have developed complex tense-aspect systems: those that have had close contacts with Turkic languages sometime in the course of their histories. Hungarians were in close contact with West-Turkic tribes in the 7th and 8th centuries, when they belonged to various Turkic tribal alliances in the area between the Dneper and the Dnester. The Hungarian tribal alliance settling in the Carpathian Basin in the 9th century incorporated a Kabar tribe and other Turkic fragments, and - as is reported in De administrando imperio by Constantine Porphyrogennetos Hungarians and Turks spoke each other's languages (cf. Sándor 2011). The other four Uralic peoples with Turkic contacts, the Udmurts, the Komi, the Mari, and the Mordvins, have shared their habitat with Turkic peoples along the Volga and Kama rivers for the past thousand years.

The Old West Turkic language that could influence Hungarian is known from inscriptions and other documents, and a present-day descendant, the Chuvas language. According to Erdal's Old Turkic Grammar (2004), Old Turkic had complex tense forms structured the same 
way as the complex verbs of Old Hungarian, consisting of a lexical verb bearing an aspect marker and an agreement marker, and a copula bearing a tense or mood suffix. In Old Turkic complex verb forms, the aspect marker on the lexical verb and the tense marker on the copula appear to be identical, and they are both glossed as tense suffixes, but the one on the lexical verb is said by Erdal to express taxis, i.e., relative tense. (7) contains an example of Old Turkic past perfect, and (8) is an example of Old Turkic conditional perfect:

(7) öydün sözlä -di-Ø är-di

earlier say-PAST-3SG be-PAST

'he had said (it) earlier' (Erdal 2004, 245)

(8) te-di-miz är-sär

say-PAST-1PL be-COND

'we would have said (it)'

(LeCoq 2011)

In Chuvash, the only present-day descendant of West old Turkic, the $b e+$ past complex has cliticized to the lexical verb marked for taxis and agreement, as a result of which the agreement suffix appears in the middle of the inflected verb:

(9) Şyra-tt-ăm-ččĕ ${ }^{1}$

work-DURATIVEPAST-1SG-be.PAST

'I was working'

şyr-satt-ăm-ččě

work-PRETERIT-1SG-be.PAST

'I had worked'

The complex verb forms of the Uralic languages along the Volga-Kama rivers are structured similarly. As illustrated by the Udmurt and Mari examples in (10) and (11) cited from Bereczki (1983), the agreement marker is on the lexical verb; the copula is only marked for tense.

\footnotetext{
${ }^{1}$ The Chuvash data have been provided by Klára Agyagási, Debrecen University.
} 
(10) Udmurt:
a. mịniśk-em
go-PERF.1SG
b. mịniśk-em val
'I went'
go-PERF.1SG be.PAST
'I had gone'

(11) Mari:
a. tolön-am
b. tolə̈n-am
äl'e
come-PERF.1SG
come-PERF.1SG be.PAST
'I came'
'I had come'

Aspect is marked on the lexical verb, preceding agreement, as shown by the following Komi minimal pair of Bereczki (1983):

(12) Komi:
a. mun-a vęli
b. mun-ȩm-a vȩli
go-1SG be.PAST
go-PERF-1SG be.PAST
'I was going'
'I had gone'

The fact that the Old Turkic and the Old Hungarian verbal complexes are structured similarly could also be a coincidence, although the close contacts of Turks and Hungarians in the Proto-Hungarian period are documented in historical sources. However, if the complex tenses of Old Hungarian were the result of internal development, we would not expect to find similar complex tenses also in the four Uralic languages that happen to be spoken in an area co-habitated by Turkic peoples. The fact that verbal complexes of the Turkic type are attested in all and only the languages of the Uralic family that have come into close contacts with Turkic peoples suggests that the complex tenses of these languages have evolved owing to Turkic contact effect.

\section{The evolution of Hungarian complex tenses}

Grammatical borrowing presupposes a bilingual situation (cf. Bowern 2005), which can be plausibly assumed for large sections of the 7th-9th-century Hungarian population. (The administrative and military governability of the Turkic-Hungarian tribal alliances required a common language shared at least by the elites of the allied tribes.) In a bilingual situation, a scenario of the grammar of L2 influencing the grammar of L1 involves the reanalysis of a 
construction of L1 according to rules of L2. This is how the borrowing of complex verb forms from Old Turkic might also have happened.

The Uralic languages abound in participles and gerunds, which can have overt subjects, and can agree with them. Hungarian, for example, has a type of gerund derived by the suffix $t$, which has a subject of its own, eliciting possessive agreement on the gerund. This type of gerund must be Ugric, or perhaps Uralic, heritage, as Khanty, a Ugric sister language of Hungarian, also has it (see Nikolaeva 1999, 47). For example:
(13) Hazafelé men-t-em-kor eleredt az eső. homewards go-GERUND-1SG-at started the rain 'During my going home, it started to rain.'

This type of gerund could - and still can - easily occur as the subject in a copular clause, e.g.:

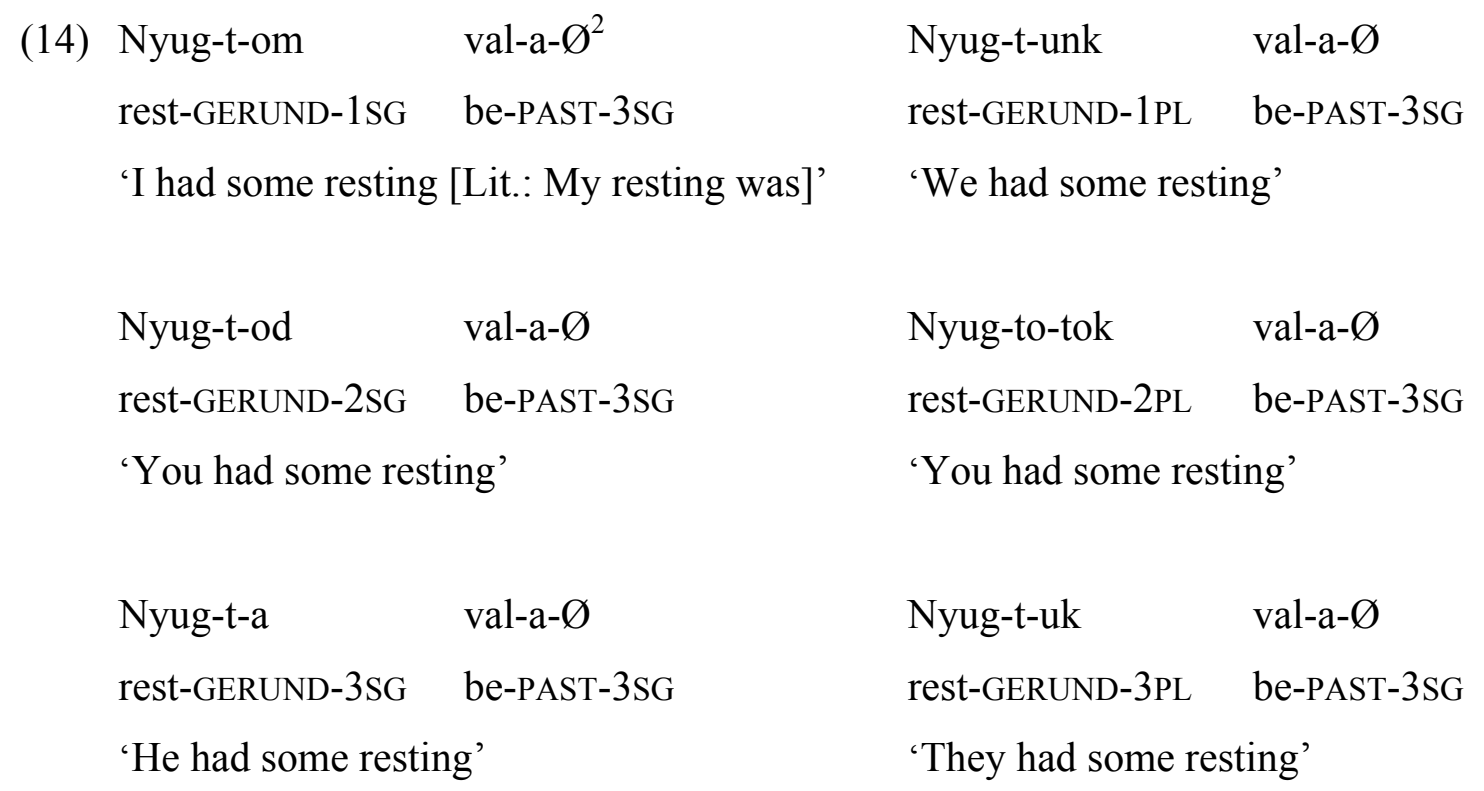

The construction in (14) is structured similarly to the past perfect verb form of Old Turkic. The $-t$ - gerundive suffix appears in the same position as the Old Turkic - di-aspectual suffix, and is also formally similar to it. Consequently, children acquiring Proto-Hungarian in a biligual situation could easily identify the feature content of the Hungarian - $t$ - with that of the

\footnotetext{
${ }^{2}$ The example is a reconstructed Old Hungarian structure. In the Modern Hungarian version, the past tense marker of the copula is $-t$, and the gerund has a somewhat idiomatic meaning, i.e.:

(i) Nyug-t-om vol-t-Ø

rest-GERUND-1SG be-PAST-3SG

'I had some resting [I wasn't disturbed]'
} 
Turkic - $d i$-, i.e., they could interpret the $-t$ - as a perfective morpheme. The possessive agreement on the gerund is non-distinct from verbal agreement, hence it could easily be reanalyzed as such. ${ }^{3}$ The possessor, represented by a silent pro in (14), was caseless, hence it could also be interpreted as a nominative subject. The $3 \mathrm{rd}$ person singular agreement morpheme on the copula is phonetically null, which facilitated the reanalysis of the copula as the carrier of a mere tense morpheme. That is:

\section{(15) Reanalysis}

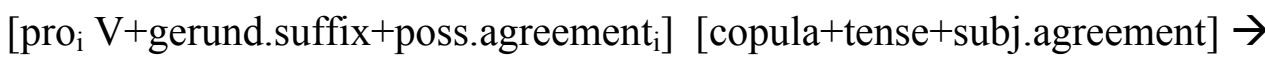
pro $_{i}[\mathrm{~V}+\text { aspect }+ \text { subj.agreement }]_{\mathrm{i}} \quad[$ auxiliary+tense $]$

For example:

(16)
pro men-t-em
1SG go-GERUND-POSS.1SG be-past-3SG
val-a-Ø
$\rightarrow$ pro men-t-em val-a
1SG go-PERF-1SG be-PAST
'My going was'
'I had gone'

The change in the feature content of $-t-$, and the reanalysis of the gerund + copula string as a past perfect verb form must have triggered further changes. The - $t$ - perfect morpheme could be removed from the past perfect paradigm, and in the resulting verb form, the lack of an overt element in the position of the aspectual morpheme was interpreted as the marker of imperfective/continous aspect. Thus the analogical extension of the past perfect paradigm yielded a past imperfective/continous paradigm, as well:

\section{(17) Analogical extension}

$\begin{array}{lllll}\text { men-t-em } & \text { val-a } & \rightarrow & \text { men-Ø-ek } & \text { val-a } \\ \text { go-PERF-1SG } & \text { be-PAST } & & \text { go-IMPERF-1SG } & \text { be-PAST } \\ \text { 'I had gone' } & & & \text { 'I was going' } & \end{array}$

\footnotetext{
${ }^{3}$ More precisely, Hungarian uses both definite and indefinite verbal paradigms, depending on whether or not the verb has a definite object. The singular possessive agreement suffixes are identical with the singular agreement suffixes of the definite verbal paradigm, and the plural possessive agreement suffixes are identical with the plural agreement suffixes of the indefinite verbal paradigm.

${ }^{4}$ The stem of men-ek also has a megy allomorph.
} 
The establishment of the past perfect paradigm opened up a further possibility: omitting the past tense morpheme and its copula carrier resulted in a present perfect verb form:

(18) Abstraction:

$\begin{array}{llll}\text { men-t-em } & \text { val-a } \rightarrow & \text { men-t-em } \\ \text { go-PERF-1SG } & \text { be-PAST } & & \text { go-PERF-1SG } \\ \text { 'I had gone' } & & \text { 'I have gone' }\end{array}$

In sum: in a bilingual situation, the structural and morphological similarity of the ProtoHungarian $-t$ - gerund + copula string and the Old Turkic past perfect verbal complex made it possible for children acquiring Proto-Hungarian to assign the structure of the Old Turkic construction to the Hungarian expression. The emergence of the past perfect paradigm in Proto-Hungarian initiated further changes: the removal of the perfect morpheme yielded a past imperfective paradigm, and the removal of the past tense auxiliary yielded a present perfect paradigm.

\section{The emergence of situation aspect marking}

The tense-aspect system that evolved in Proto-Hungarian combines tense marking with viewpoint aspect marking, expressing morphologically whether the speaker's perspective includes a whole, completed event, or only the internal section of an event. At the same time, the very first Old Hungarian documents already carry the germs of an alternative aspectual system, as well, which distinguishes telic events, having an inherent endpoint, from atelic events with no inherent endpoint, by means of a resultative or terminative verbal particle. Verbal particles are claimed to have already existed in the Ugric proto-language (Honti 2001). They are attested in the Ugric sister languages of Hungarian, too. Their occurrence in the early Old Hungarian documents is still sporadic. In the Funeral Sermon and Prayer (1195), we find a single resultative verbal particle:
(19) turchucat
mige zocozt-ia
vol-a
throat.3pl.ACC
PRT burst-IMPERF.3SG
be-PAST
'it was bursting up their throat'

In the rest of the clauses of this text, telicity is marked by perfect verbal morphology (20a), by the context (20b), or by the lexical meaning of the verb (20c): 

(20) a. es odut-t-a vol-a neki paradisumut hazóá and give-PERF-3SG be-PAST him Paradise.ACC house.for 'and had given him Paradise for a house'
b. es vetev-e wt ez muncas vilagbele and throw-PAST.3SG him this laborious world.into 'and threw him into this laborious world'
c. hug isten ív uimadsaguc-mia bulsas-s-a w bunet that God they prayer.3PL-because.of forgive-SUBJ-3SG he sin.3SG.ACC 'so that God forgive his sin because of their prayer'

In the 14th-15th centuries, we attest the fast spreading of verbal particles. Jókai Codex, containing a translation of the Legend of Saint Francis from around 1370, already abounds in particle verbs. We have an interesting 'snapshot' from the end of the 15th century of their gaining ground, the so-called München Relic (Haader 2004). A German monk interested in the Hungarian language described the Lord's Prayer in Hungarian in two versions. One version seems to have been copied in Hungarian spelling from a written source. The other version is the transcription in German spelling of how the scriptor heard the prayer from a Hungarian native speaker. The version copied from a written source, representing somewhat earlier usage, still has no verbal particles. The version recording the oral prayer, on the other hand, already has three of them:
(21) ës meg-bozässät mi vëtkenkët. mikëpen ës mi mag-boczätunk and PRT-forgive.IMP.2SG we sin.1PL.ACC as also we PRT-forgive.1PL vëtëtëknek ... de säbädicz-mk mikët a gonostwl sinners.DAT but free.IMP.2SG-PRT us the evil.from 'and forgive us our debts, as we also forgive our debtors... but deliver us from evil'

The Lord's Prayer in the Bible translation of Gáspár Károli from 1590 contains four more verbal particles:
(22) szenteltesséc
meg à te neued. Iöijön
el az te országod: 
hallow.PASS.IMP.3SG PRT the you name.2SG come.IMP.3SG PRT the you country.2SG Légyen meg à te akaratod... Az mi minden napi kenyerünket add be.IMP.3SG PRT the you will.2SG the our every day bread.ACC give.IMP.2SG meg nékünc ma.

'Hallowed be your name. Your kingdom come, your will be done... Give us this day our daily bread'

By the Middle Hungarian period (1526-1772), most process verbs had developed particle versions. ${ }^{5}$ The particle verbs assumed telic, accomplishment meanings, and the bare verbs came to be confined to atelic contexts, as shown by the following minimal pairs from the Legend of Saint Margaret (1510):

a. ker vala hust ... es meg fevży vala pro $^{6}$ ask.IMPERF.3SG be.PAST meat.ACC and PRT cook.IMPERF.3SG be.PAST it.ACC 'she would ask for meat ... and would cook it' (p. 26 verso)

b. mert akoron az kÿs setet kohnyaban fevznek vala because then that small dark kitchen.in cook.IMPERF.3PL be.PAST 'because then they used to cook in that small dark kitchen' (p. 66 verso)

(24)

a. es meg allanak ez beteg soror agÿanal az zentek and PRT stand this sick soror's bed.at the saints.NOM 'and the saints would stop at the bed of this sick soror' (p. 63 recto)
b. Mykoron ez soror egÿ napon az karban allana az ablacnal when this soror one day the chorus.in stand.COND.3SG the window.at 'When this soror was standing in the chorus at the window one day' ( $p .73$ verso)

The development of atelic-telic verb pairs must have been inspired by Slavic. Hungarians settling in the Carpathian basin in the 9th century found a Slavic population there, which they

\footnotetext{
${ }^{5}$ Unergative verbs are exceptions. The particle predicates the resulting state of the theme argument, hence unergative verbs can only be bounded by a verbal particle if they take a non-thematic object - see É. Kiss (2006).

${ }^{6}$ The presence of this object pro can be reconstructed from the definite conjugation of the verb.
} 
absorbed, and this process must have involved the bilingualism of large sections of the population for more than one generation. Hungarian borrowed hundreds of words from Slavic, and the grammar of the Slavic substratum is also likely to have influenced Hungarian grammar. In the Slavic language, telicity is systematically marked by a verbal prefix, e.g., čitat' means 'to read', pro-čitat' means 'to read from beginning to end'; delat' means 'to do, to make', sdelat' means 'to do, to make completely' (Borik 2002). Old Hungarian verbs supplied with a prefix-like preverbal verbal particle were also all telic (see (19)), but bare verbs could be either atelic, or telic (as shown by examples (20a-c)). That is, whereas the aspectual properties of prefixed/particle verbs were similar in Slavic and in Hungarian, the aspectual roles of bare verbs were different:

Slavic verb types: $\quad$ prefixed verbs $\leftarrow \rightarrow$ bare verbs

$$
\text { [+ telic] [-telic] }
$$

Old Hungarian verb types: particle verbs - bare verbs

$$
\text { [+ telic }] \quad[+/ \text {-telic }]
$$

Slavic contact effect must have resulted in the reanalysis of the aspectual feature of Hungarian bare verbs from [+/- telic] to [-telic]:

\section{(25) Reanalyis:}

particle verbs - bare verbs $\rightarrow$ particle verbs $\leftarrow \rightarrow$ bare verbs

$$
[+ \text { telic }] \quad[+/ \text {-telic }] \quad[+ \text { telic }] \quad[\text {-telic }]
$$

The resulting aspectual contrast was analogically extended to all transitive and unaccusative verbs (unergatives being unable to take particles - see footnote 4); practically all bare verbs developed versions with a resultative or terminative particle. ${ }^{7}$ The reanalysis of verbal particles as the carriers of telicity did not affect their syntax, though. Whereas Slavic telicizing prefixes are bound morphemes, the Hungarian verbal particle has preserved the syntactic independence that it had in early Old Hungarian. In neutral sentences, it immediately precedes the verb, but in negative sentences and in focus constructions, the verb is raised across the particle.

\footnotetext{
${ }^{7}$ For evidence, see É. Kiss (2006).
} 


\section{The fall of complex tenses}

The micro-change in the feature content of bare verbs, resulting in the evolution of aspectual verb pairs and the systematic distinction of [+/- telicity], has eventually led to a macrochange: the emergence of situation aspect marking made viewpoint aspect marking redundant, and led to the disappearance of complex tenses.

In most cases, atelic events are imperfective, and telic events are perfective. However, 15th century Hungarian was also capable of systematically encoding mismatches between the two types of aspect, describing, e.g., incomplete telic events (26) or incomplete series of telic events (27), by combining a telicizing verbal particle with an imperfective verb form (Geröcs 2011):

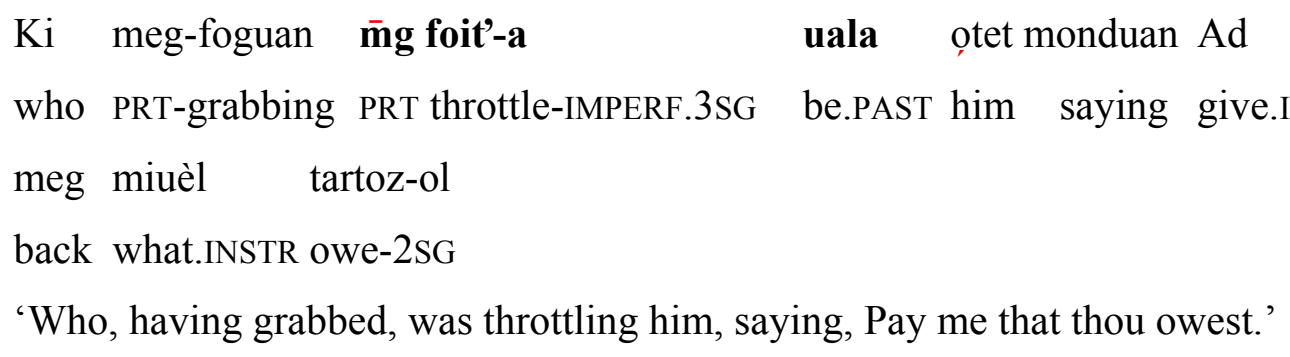

(München Codex 1416, p. 24 verso)

(27) kikèt akar uala meg-ol uala who.PL.ACC want.IMPERF.3SG be.PAST PRT-kill.IMPERF.3SG be.PAST kikèt akar uala meg-uèr uala who.PL.ACC want.IMPERF.3SG be.PAST PRT-beat.IMPERF.3SG be.PAST 'whom he would he slew; whom he would he put down' (Vienna Codex 1416, p. 143)

Such mismatches between situation aspect and viewpoint aspect, however, were not common enough to support the coexistence of two aspectual systems. It was viewpoint aspect marking that started fading. As a first step, the present perfect blended functionally with the simple past, eventually supplanting it completely. Val-a 'be-PAST', the temporal auxiliary of the past perfect and past continuous paradigms, was also more and more often replaced by vol-t 'be-PERF', as a consequence of which the same suffix appeared in the positions of both the tense marker and the aspect marker in complex verb forms, increasing the confusion.

(28) $\mathrm{Ki}$ hallot-t-a vol-t valamikoron ezt hog az zentoknec coronaia who hear-PERF-3SG be-PERF ever this.ACC that the saints.DAT crown.POSS 
tọviskel coronaztassec

thorn.with crown.PASS.SUBJ.3SG

'Who had heard before that the saints' crown be crowned with thorns'

(Döbrentei Codex 1508, p. 5 verso)

The use of volt in the past continous (29) indicates that by beginning of the 16th century $-t$ had lost its perfectivity feature; it simply marked past events, rather than past events with a present result:

$\begin{array}{lllll}\text { Wgh mond zenth agoston } & \text { ky } & \text { thaneyt-ya } & \text { vol-t } & \text { oteth } \\ \text { so } \quad \text { says Saint Augustin } & \text { who teach-IMPERF.3SG } & \text { be-PERF him }\end{array}$

'Saint Augustin, who was teaching him, says so' (Winkler Codex 1506, p. 107 recto)

By the end of the Middle Hungarian period (1526-1772), the - $t$-marked past tense had become practically the only productively used non-present tense. The -a/e marked simple past and the complex tenses occurred less and less frequently; they were mostly used as stylistic variants without any clear aspectual value in elevated, literary texts. By now, Hungarian has returned to the dual Uralic tense system consisting of a past and a non-past, except that the Uralic past tense morpheme has been replaced by $-t$-, the Old Hungarian perfectivity marker. Viewpoint aspect morphology has been lost; its function has been taken over by situation aspect marking.

A similar process, i.e., the replacement of morphological viewpoint aspect marking by situation aspect marking via verbal prefixes, has been attested in several Slavic languages, as well. Kiefer (2010) regards the aspectual function of preverbs a Sprachbund phenomenon whose central area is Slavic, and which also comprises Hungarian, Lithuanian, Yiddish, German and Romani.

The changes that have taken place in the morphosyntax of Hungarian verbal inflection can be interpreted structurally as follows: the projection hosting the verbal particle, labelled as PredP (cf. Koster 1994), has been reanalyzed as AspP, whereas the projection hosting the $-t$ suffix, labelled as AspP, has been reanalyzed as TenseP - see (30a,b). The original TenseP projection, harboring the auxiliary vala, disappeared. That is: 


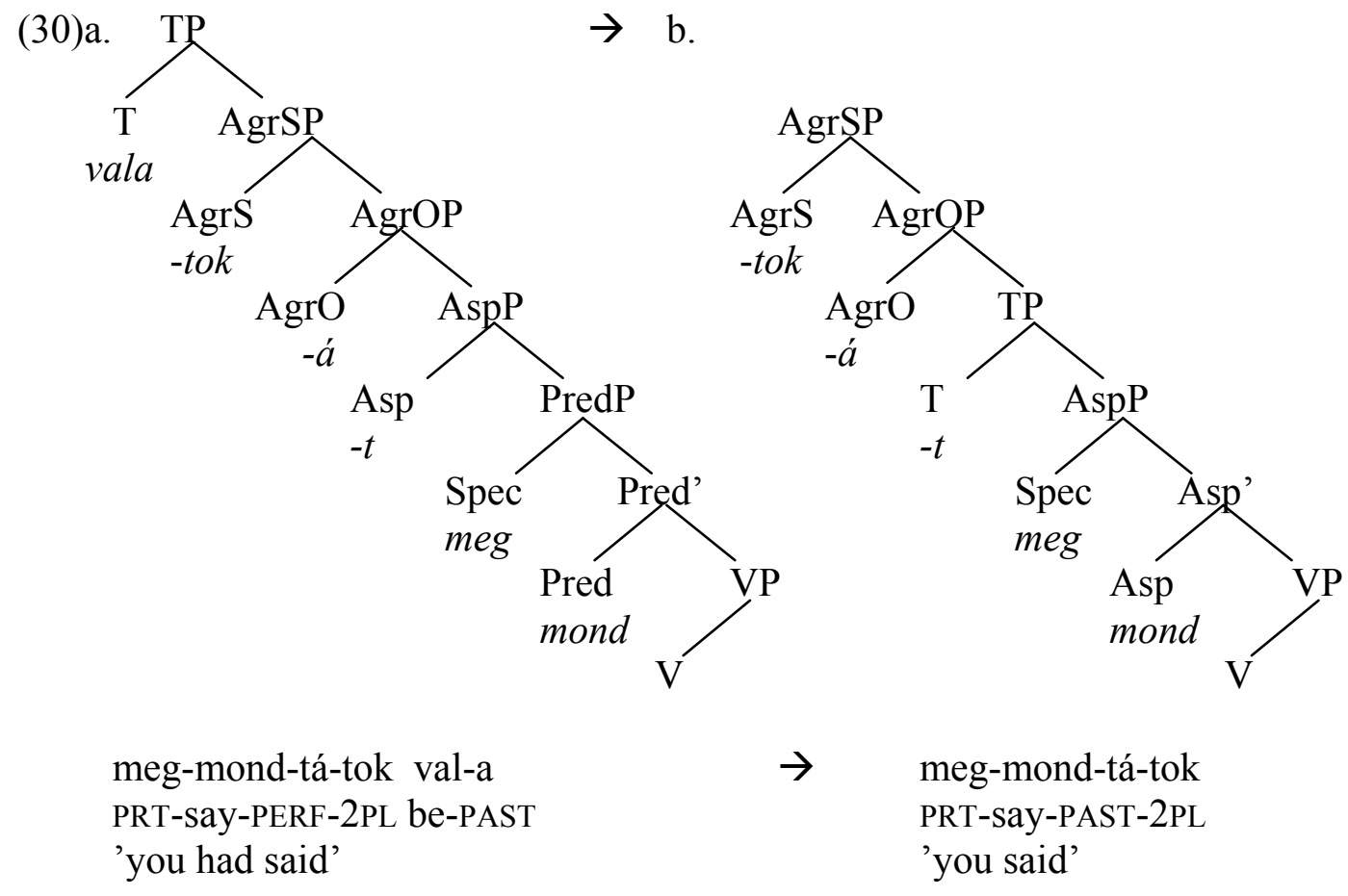

\section{Theoretical implications}

Claims of contact-induced syntactic changes appear to be rarer in historical linguistics than claims of lexical and morpho-phonological contact effects. This paper has demonstrated through the case of the Hungarian verbal complex that contact effects can lead to pervasive changes in syntax, too. The syntactic interference of a second language presupposes the acquisition of the mother tongue in a bilingual environment; but bilingualism is believed to have been very common throughout the history of mankind.

Perhaps the most basic question of contact linguistics is what can, and what cannot change in a contact situation; what triggers and what restricts contact-induced changes. The licensing conditions of the two contact-induced syntactic changes of Hungarian discussed in this paper, the evolution of verbal complexes marking both tense and viewpoint aspect, and a thousand years later, the replacement of viewpoint aspect marking by situation aspect marking via verbal particles, suggest a possible answer. In both cases, Hungarian had a syntactic construction that resembled a construction of the lender language formally and functionally. In both cases, a translinguistic reanalysis took place: Hungarian speakers assigned to the Hungarian construction the structural-functional properties of the construction of the contact language. That is, these contact-induced syntactic changes involved the same mechanism that is attested in internal changes - apart from the fact that the trigger came from a second language. 
Originally, the change may have been a micro-change altering the feature content of a single element: the reanalysis of a non-finite suffix as a perfectivity marker, or, the reinterpretation of the [+/-telic] feature of verbs with no resultative particle as [-telic]. These micro-changes, however, had major consequences. The featural change altered the category of the given morpheme, which necessitated the reanalysis of the phrasal constituents subsuming it. Thus the reanalysis of the $-t$ - gerundive suffix as a perfectivity marker led to the reanalysis of the gerund phrase as a finite verbal complex, and this also involved the reanalysis of the possessive agreement on the gerund as verbal agreement, the reanalysis of its genitive subject as a nominative subject, and the reanalysis of the copula as a temporal auxiliary. In the course of the emergence of situation aspect marking, the assignment of a [-telic] feature to verbs with no verbal particles led to the reinterpretation of the verbal particle as the canonical marker of telicity, and the reanalysis of the projection harboring it as an aspectual phrase. The reanalyzed constructions could serve as input to further changes, for example, analogical extension and abstraction. Thus the removal of the perfectivity marker from the "perfect lexical verb + past auxiliary' complex expressing past perfect yielded a past continous paradigm, whereas the removal of the past tense auxiliary yielded a present perfect paradigm. A thousand years later, the development of viewpoint aspect marking by means of verbal particles led to the obsolescence of the complex tense system marking both tense and viewpoint aspect, leaving in place only two simple tenses: past and non-past.

\section{Sources of examples:}

Döbrentei Codex. 1508, Csilla Abaffy, Csilla T. Szabó \& Edit Madas eds. Régi magyar kódexek 19. Budapest: Argumentum, 1995.

Funeral Speech and Prayer [Halotti beszéd és könyörgés]. 1192-95. In: Magyar nyelvemlékek, József Molnár \& Györgyi Simon ed. Budapest: Tankönyvkiadó, p. 27. 1977. Jókai Codex. 1370/1448, János P. Balázs ed. Budapest: Akadémiai Kiadó, 1981. Legend of Saint Margaret [Margit-legenda].1510, János P. Balázs, Adrienne Dömötör \& Katalin Pólya eds. Régi magyar kódexek 10. Budapest: Magyar Nyelvtudományi Társaság, 1990.

München Codex. 1416-35/1466, Antal Nyíri ed. Budapest: Akadémiai Kiadó, 1971.

Vienna codex [Bécsi kódex]. 1416-1435/1450, Gedeon Mészöly ed. Budapest: Magyar Tudományos Akadémia, 1916.

Winkler Codex. 1506, István Pusztai ed. Codices Hungarici 9. Budapest: Akadémiai Kiadó, 1988. 


\section{References:}

Bereczki, Gábor, 1983. A Volga-Káma-vidék nyelveinek areális kapcsolatai [Areal contacts of the languages of the Volga-Kama area]. In: János Balázs, ed. Areális nyelvészeti tanulmányok. Budapest: Tankönyvkiadó, 207-237.

Bereczki, Gábor 1993. The character and the scale of Turcic influence on the structure of Finno-Ugric languages. In: Béla Brogyányi and Reiner Lipp, ed. Comparative-Historical Linguistics: Indo-European and Finno-Ugric. Amsterdam: John Benjamins, 501-519.

Borik, Olga 2002. Aspect and Reference Time. Utrecht: LOT.

Bowern, Claire 2005. Syntactic change and syntactic borrowing in generative grammar. In: Gisella Ferraresi and Maria Goldbach, eds. Principles of Syntactic Reconstruction. Amsterdam: John Benjamins, 187-216.

E. Abaffy, Erzsébet, 1991. Az igemód- és igeidő-rendszer [Verbal mood and tense]. In: Loránd Benkő, ed. A magyar nyelv történeti nyelvtana I. A korai ómagyar kor és elözményei. Budapest: Akadémiai Kiadó, 104-121.

É. Kiss, Katalin, 2006. From the grammaticalization of viewpoint aspect to the grammaticalization of situation aspect. In: Katalin É. Kiss, ed. Event structure and the Left Periphery. Studies in Natural Language and Linguistic Theory. Dordrecht: Springer, 129158.

Erdal, Marcel 2004. A Grammar of Old Turkic. Leiden: Brill.

Gerőcs, Mátyás, 2011. Aspektus és igekötő. A mondat belső időszerkezete a kései ómagyarban [The internal temporal organization of the sentence in Old Hungarian]. In: Katalin É. Kiss and Attila Hegedűs, eds. Nyelvelmélet es diakrónia. Budapest-Piliscsaba: Szent IstvánTársulat, 153-170.

Haader Lea 2004. Nyelvi szempontú megjegyzések a Müncheni emlékhez [Linguistic remarks on the Munich relic]. Magyar Nyelv 101: 161-178.

Hegedüs, Attila and Lajos Papp 1991. Középkori leveleink 1541-ig. Budapest: Tankönyvkiadó.

Honti, László 2001. A magyar igekötő: nyelvünk kései jövevénye? [Is the Hungarian verbal particle a latecomer in our language?] In: Marianne Bakró Nagy, Zoltán Bánréti and Katalin É. Kiss, eds. Újabb tanulmányok a strukturális magyar nyelvtan és a nyelvtörténet köréből. Budapest: Osiris, 357-367. 
Kiefer, Ferenc 2010. Areal-typological aspects of word-formation. In: Franz Rainer, Wolfgang U. Dressler, Dieter Kastovsky and Hans Christian Luschützky, eds. Variation and Change in Morphology. Amsterdam: John Benjamins, 129-148.

Koster, Jan, 1994. Predicate incorporation and the word order of Dutch. In: Guglielmo Cinque, Jan Koster, Jean-Yves Pollock, Luigi Rizzi, and Raffaella Zanuttini, eds. Paths towards Universal Grammar: studies in honor of Richard S. Kayne. Oxford: Oxford University Press, 255-276.

LeCoq, Albert 2011. Chuastuanift, ein Sündenbekenntnis der manichäischen Auditores gefunden in Turfan. Berlin: Walter de Gruyter.

http://vatec2.fkidg1.unifrankfurt.de/vatecasp/Chuastuanift_\%28Berlin\%29.htm\#134309

Nikolaeva, Irina 1999. Ostyak: languages of the world: materials 305. München: LINCOM Europa.

Sándor, Klára 2011. Nyelvrokonság és hunhagyomány. Budapest: Typotex.

Sárosi, Zsófia, 2003. Morfématörténet. Az ősmagyar kor [The history of morphology: The Proto-Hungarian period]. In: Jenő Kiss and Ferenc Pusztai, eds. Magyar nyelvtörténet. Budapest: Osiris, 129-172. 